\title{
Priestly Violence, Martyrdom, and Jesuits: The Case of Diego de Alfaro (Paraguay, 1639)
}

\author{
Andrew Redden
}

It does not diminish his glory in any way [... to say that he died of a bullet [while] fighting with a shotgun in his hand, captaining the Indians [for] it is licit, just and holy to kill the one who attacks the innocent, defending him or her when he or she would otherwise be defenseless. ${ }^{1}$

The question of what makes a Jesuit, the quidditas jesuitica, is thrown into stark relief by the extraordinary case of Diego de Alfaro (d.1639) and its apologia, written in 1644 by the former provincial of the Paraguayan province, Diego de Boroa (d.1657). ${ }^{2}$ Alfaro-superior of the missions of Guairá in the province of Paraguay-took up arms in 1639 and fought alongside his Guarani faithful against bandeirantes (slave raiders) from the Portuguese city of São Paulo; in the gunfight with these slavers, Alfaro was killed. Portuguese and Spanish detractors of the Society alike decried the scandal of a priest under arms, yet the Jesuits of the Paraguayan province rallied around their provincial in defending Alfaro's actions as both heroic and virtuous. From their perspective, his actions were necessary, and he was, according to Boroa's apologia, even a martyr for the faith.

Documented cases of fighting Jesuits are, it would seem, extremely rare, and Boroa's letter defending Alfaro's actions is also remarkable in the claims it makes. Yet, the contention of this essay is first that the presence of the Jesuits in frontier missions around the Paraguay and Uruguay rivers was essential to the way events unfolded in the region, the very same events that brought about Alfaro's violent death. Second, it was Alfaro's Jesuit formation and mission that

1 Diego de Boroa, "Apología y defensorio de la gloriosa muerte del P.e Diego de Alfaro, 18 Enero 1644," ARSI, Paraq. 11, fol. 263r. This and all other translations, unless otherwise stated, are my own. My thanks are due to Mauro Brunello of the Archivum Romanum Societatis Iesu (hereafter ARSI) for his assistance in the research of various aspects of this essay.

2 Boroa was provincial of Paraguay between 1634 and 1640 after which he once again became rector of the College of Córdoba de Tucumán until 1644. Thus he was provincial of Paraguay when Alfaro was killed, and rector of the College of Córdoba when he wrote the apologia (Diccionario histórico de la Compañía de Jesús, ed. Charles E. O’Neill and Joaquín Ma. Domínguez [Rome: Institutum Historicum Societatis Iesu, 2001], 1:495). 
led him to act in the way he did; while third, the essay will argue that the quidditas jesuitica was fundamental to the way in which Jesuits (and Boroa in particular) perceived and portrayed these events in order to defend the missions and their populations against their enemies. In order to make this argument, the essay draws primarily on Jesuit sources from the province of Paraguay and, in particular, the above-cited apologia by Boroa, who wrote the letter in 1644 with multilayered intentions. In the first instance, it was a necessary justification of the actions of the Jesuits of the province to their superiors in Rome-in particular, the superior general Muzio Vitelleschi (in office 1615-45) and his successor Vincenzo Carafa (in office 1646-49). ${ }^{3}$ Ultimately, the superior general was the one who had to advise and instruct his subordinates on what they should or should not do, especially under such conflictive circumstances, always maintaining the difficult equilibrium between correct moral action based on sound theology and pragmatic politics in a context that could potentially have much wider implications for the work of the Society in those areas controlled by the Spanish and the Portuguese. ${ }^{4}$

Second, the letter was crafted to refute those detractors of the Society who were using the scandal of a Jesuit under arms to their advantage (and to the Society's disadvantage). Boroa more than managed to repudiate the accusations of the Society's enemies, as we shall see below, by drawing on his own highly versatile Jesuit education, the Ratio studiorum, which was a program whose aim was, "to develop intellectually curious thinkers who could do more than simply repeat dogma." ${ }^{5}$ His apologia exemplifies the success of this

3 The letter was directed to Muzio Vitelleschi who was the superior general until his death (February 9, 1645). According to a note on the back of the copy held in the ARsi, Boroa's letter was replied to on November 30, 1646. As such, the reply would have come from Vincenzo Carafa who was elected superior general on January 7,1646 , or either of the secretaries of the Society: Alexander Gottifredi (in office 1644-46) or Ludovico Bompiani (in office 1646-April 24, 1649) (Johannes B. Goetstouwers, Synopsis historiae Societatis Iesu [Leuven: Typis ad Sancti Alphonsi, 1950]), 29-30, 82, 86.

4 Unfortunately, the copy of the reply to Boroa's letter (in Epp. Gen.) that would normally be kept in Rome is not held by the ARSI - I am grateful to Mauro Brunello of the ARsI for verifying this. Further research is necessary to discover if the original letter can be located in the Jesuit collections in the Archivo General de la Nación de Argentina or the regional archives of Córdoba de Tucumán. As yet, I have not been able to locate the reply and so, unfortunately, a consideration of the superior general's response (and thus the official Jesuit position) is beyond the scope of this particular essay which will therefore be limited to a consideration of the opinion of the Jesuits of the province of Paraguay, linked to broader currents of (Jesuit) scholarly thought.

5 Benjamin Hill, "Introduction," in The Philosophy of Francisco Suárez, ed. Benjamin Hill and Henrik Lagerlund (Oxford: Oxford University Press, 2012), 16. 
Jesuitical pedagogical goal by combining a range of genres and sources (contemporary and historical context, historical precedent, scripture, Scholastic and casuistic treatises - a number of those also written by Jesuit intellectuals) in order to construct a discourse that successfully deflected and inverted contemporary anti-Jesuit vitriol. What is more, it turned what could have become a public relations disaster for the Society — the scandal of a priest breaking canon law and bearing arms-into a powerful eulogy for Jesuit action and even a martyrology for Alfaro.

The third goal of the letter was to add an authoritative intellectual argument to the intense and ongoing lobbying by the Society to persuade the Spanish authorities (in particular the viceroys of Peru, the Council of the Indies, and King Philip IV [r.1621-65]), to take action against the bandeirantes while also permitting the mission populations to be trained in modern warfare so they could properly defend themselves. The support of the papacy was also crucial and it is perhaps no coincidence that Pope Urban VIII (r.1623-44) promulgated Commissum nobis - a bull directed primarily at those who enslaved indigenous populations in the Río de la Plata region — in April 1639, only four months after Alfaro's death. This is not to suggest that Urban VIII was swayed by knowledge of Alfaro's death; it would have been too soon after the event for this news to have reached Rome and generated such a speedy response. ${ }^{6}$ Rather, Urban VIII's bull and the excommunication of the Paulista bandeirantes who continued to engage in the slave trade coincided with the climax of assaults on the missions (which included the death of Alfaro) and the subsequent beginning of the turning of the tide in the mission-Guarani's favor. Boroa's apologia formed part of this urgent Jesuit campaign to bolster support for the missions, to deflect political attacks against the Society in the province of Paraguay, and to gain approval for an appropriate military response from the mission populations themselves. ${ }^{7}$ The contextual Jesuit sources also used in this essay, such as the

6 The earliest letter in the ARsI to recount this specific event to outside of the province of Paraguay was an unsigned letter (although presumably written by Boroa) to the king, dated October 11, 1639, written in Córdoba de Tucumán (with a copy sent to the superior general Muzio Vitelleschi, in Rome): Diego de Boroa (?), "11 Oct 1639, tanto de una mi[siv]a p[ar]a el Rey ñro S[eñ]or en q[ue] le doy quenta de las agresiones de los portugeses y muerte del P.e Diego de Alfaro. Para ñro P.e General," ARSI, Paraq. 11 1600-1695, fols. 258r-259v. The letter is dated "October" in the title details but ends with the date "September 11, 1639."

7 It is worth bearing in mind that this lobbying by Jesuits of the crown for greater protection of the indigenous peoples and for the protection of their rights as subjects of the crown that they ministered to was part of a much wider tradition of ecclesiastical lobbying throughout the sixteenth and seventeenth centuries. The most famous of these clerical campaigners was the Dominican friar Bartolomé de las Casas (d.1566) who wrote numerous polemics including 
earlier letters to Rome by Simón Maceta (d.1658), Justo Mancilla van Surque (d.1666), ${ }^{8}$ and Boroa when he was still rector of the College of Asunción (1626-30), together with the chronicle La conquista espiritual written by Antonio Ruiz de Montoya (d.1652), similarly formed part of this wider political campaign to lobby both Rome and the Spanish crown for intervention. ${ }^{9}$ Ruiz de Montoya, for example, was sent by Boroa (who was then provincial) as special procurator to the Spanish court in 1637 to persuade the king to enact and enforce laws to protect the Guarani population. ${ }^{10}$ After much debate in the Spanish court, the king finally signed the decree permitting the Guarani to use firearms on May 21, 1640, but deferred the decision to the viceroy in Lima, Pedro de Toledo y Leiva, the marquis of Mancera (d.1654; in office 1639-48). ${ }^{11}$ Thus, the Jesuit victory in the court of Madrid did not signal the end of their lobbying, just as the laws decreed by Philip IV did not end the attacks on the missions. It is possible to speculate that news of Alfaro's killing had reached Madrid by the time of the May 1640 decree; indeed, this is likely as a copy of the letter to the king informing him of

Brevísima relación de la destrucción de las Indias (Seville:1552) and the Apología o declaración y defense universal de los derechos del hombre y de los pueblos (c.1552) among others (for versions in English see $A$ Short Account of the Destruction of the Indies, ed. by Anthony Pagden [Harmondsworth: Penguin Classics, 1992] and In Defense of the Indians, trans. and ed. by Stafford Poole [DeKalb: Northern Illinois University Press, 1992]). Las Casas presented his Apología to the court in Valladolid between the years 1550-1 in what became known as "The Great Debate" against the Aristotelian rhetorician Juan Ginés de Sepúlveda (d.1573).

8 Mancilla's Flemish name was Josse van Suerck.

9 Justo Mancilla van Surque, "Octub 2 de 1629," ARSI, Paraq. 11, fols. 223r-224v; Simón Maceta, "Deste Colegio dela Bahia, y 3 de octubre de 1629," ARSI, Paraq. 11, fols. 225r-226v; Diego de Boroa, "Relacion de la persecucion que la Comp.a ha padecido en el Paraguai desde el fin del año de 1628 [h] asta el de 31. A ñro muy Reuerendo Padre Vitelleschi Preposito General de la Comp.a de Jesus," ARSI, Paraq. 11, fols. 123r-128v; Antonio Ruiz de Montoya, Conquista espiritual hecha por los religiosos de la Compañía de Jesús en las provincias del Paraguay, Paraná, Uruguay y Tape (Madrid: En la Imprenta del Reyno, 1639). An English translation is available as Antonio Ruiz de Montoya, The Spiritual Conquest Accomplished by the Religious of the Society of Jesus in the Provinces of Paraguay, Paraná, Uruguay, and Tape: A Personal Account of the Founding and Early Years of the Jesuit Paraguay Reductions (1639), trans. and ed. Clement J. McNaspy et al. (St. Louis: Institute of Jesuit Sources, 1993). The revised annotated translation of this work is forthcoming from the Institute of Jesuit Sources at Boston College.

10 Ruiz de Montoya had been the superior of the missions of Guairá between 1622 and 1636 and subsequently of all the Guarani missions until 1637. Clement McNaspy, "Introduction," in McNaspy et al., Spiritual Conquest, $15^{-17}$. Ibid., 18. 
these events was sent to Rome in November $1639 .{ }^{12}$ Nevertheless, just as it is not the purpose of the essay to speculate on the influence of Alfaro's death on the pope, nor will it speculate on the specific impact on the Spanish court. Rather, the point is merely to place his death and Boroa's apologia in a context of intense lobbying by the Society of Jesus and, in the frontier regions of Paraguay, one of general warfare that was perceived and portrayed by the Jesuits as apocalyptic.

Further Jesuit sources to be considered and compared in this essay will be the relevant Scholastic and casuistic treatises written by Boroa's near contemporaries Francisco Suárez (d.1617) and Luis de Molina (d.16oo). ${ }^{13}$ Both De charitate (On charity) from De triplici virtute (On the three virtues) by Suárez and De iustitia et iure (On justice and law) by Molina were written in an academic context, yet both aimed to provide casuistic moral guidance for figures of authority (in particular for princes and their confessors) on matters of violence and war. ${ }^{14}$ Boroa uses these and other similar treatises that consider the moral implications of warfare, of who might legitimately participate, and under what conditions. ${ }^{15}$ With the exception of Suárez, all the authorities he cites consider cases of the rights of princes and peoples to wage war and the rights of people to defend themselves. Although he does not specify which texts he has used, Boroa cites these authorities to give direct support to his argument about the justice of Alfaro's actions and the obligation of other priests to follow in his footsteps.

One might still object that Alfaro's specific actions and even Boroa's apologia would never have been approved by the superior general of the Society and as such could not be considered distinctively Jesuit. Unfortunately, if it still exists, the reply sent from Rome on November 30, 1646, just a few months after

12 Boroa(?), "11 Oct 1639, tanto de una mi[siv]a," fols. 258r-259v.

13 For Molina, I will be using João Manuel Fernandes, "Luis de Molina: On War," in A Companion to Luis de Molina, ed. Matthias Kaufmann and Alexander Aichele (Leiden: Brill, 2014), 227-55. For Suárez, I will be using an edited scholarly translation of the original text: Francisco Suárez, "The Three Theological Virtues: On Charity; Disputation XIII: On War," in Selections from Three Works of Francisco Suárez [...], ed. and trans. Gwladys Williams et al. (Oxford: Clarendon Press, 1944), 2:80o-65.

14 Suárez's De triplici virtute theologica, fide, spe \& charitate was published after his death in 1621. James Brown Scott, "Introduction," in Williams et al., Selections from Three Works of Francisco Suárez, 2:9a-10a.

15 The other Jesuit theorist that Boroa cites was Leonard Lessius (d.1623) who was Suárez's pupil in the Collegio Romano, Rome. Boroa also cites Archbishop Diego de Covarrubias y Leyva (d.1577) and the theologian Martino Bonacina (d.1631). It is beyond the scope of this study to consider all of these theologians and thus the analysis will be limited to Suárez and Molina as exemplars. 
Carafa was elected in January of that year, has yet to be located so it is impossible to know his precise response. Nevertheless, some tentative possibilities can be inferred based on the fact that missives from Rome tended to discourage actions that could lead a Jesuit into danger and certainly discouraged the seeking of martyrdom. ${ }^{16}$ Were a Jesuit to be martyred, the most commonly lauded image to inspire young novices to missionary work was that of the martyr accepting death with saintly resignation. Alfaro was himself represented in this way alongside other Jesuit martyrs in the late seventeenth-century martyrology by the Jesuit Matthias Tanner (d.1692) (see fig. 5.1). ${ }^{17}$ In this hagiographical image, Alfaro kneels submissively before his assassin with his eyes (and soul) fixed on heaven, while the battle rages in the background. What Alfaro is not doing is charging into battle, and his shotgun is nowhere to be seen.

In a similar vein, the Formula of the Institute of the Society of Jesus, approved in $155^{\circ}$ by Pope Julius III (r.1550-55), makes clear that while the Society considered a Jesuit to be a "soldier of God," he was to dedicate himself to charitable works rather than commit acts of violence. ${ }^{18}$ Ultimately, according to the Formula, a Jesuit's role was to "exercise whichever other works of charity that seem most convenient for the glory of God and the common good."19 It is here, perhaps, that Jesuit distinctiveness manifests itself most clearly. In emphasizing the need to work for the glory of God and the common good in one of its foundational documents, the Society of Jesus (and its founder Ignatius of Loyola [d.1556]) gave considerable leeway to its members to interpret what this meant according to the specific circumstances they encountered. Boroa, as we

16 See, for example, instruction 6 of the "Instructions" given to Jerónimo Ruíz de Portillo (d.1590) the first superior of the province of Peru (1568-76) prior to his departure for the Americas in 1567 by the superior general Francisco de Borja (in office $1565^{-72}$ ): "Instructión [sic] de las cosas que se encargan al Padre Portillo y a los otros Padres que van a las Indias de España en Março 1567," in Monumenta Historica Societatis Iesu (hereafter MHSI): Monumenta Peruana, ed. Antonio de Egaña (Rome: MHSI, 1954), 1:120-24: 123; and Juan Alfonso de Polanco, "Industrias con que vno de la Compañía de Iesús mejor consiguirá sus fines..." [1567], in MHSI: Polanci complementa (Madrid: Gabrielis López del Horno, 1917), 2:776-807.

17 "P. Didacus de Alfaro in America Laxamae illustri Sanguinie natus [...]" [The martyrdom of Diego de Alfaro], in Matthias Tanner, Societas Jesu usque ad sanguinis et vitae profusionem militans (Prague: Typis Universitatis Carolo-Ferdinandeae, in collegio Societatis Jesu ad S. Clementem, per Joannem Nicolaum Hampel Factorem, 1675), 503.

18 San Ignacio de Loyola, Fórmula del instituto de la Compañía de Jesús: Fórmula del año $155^{\circ}$ aprobada y confirmada por el papa Julio III, Section 1, www.raggionline.com/saggi/scritti/ es/formula.pdf, accessed March 30, 2015.

Ibid. 


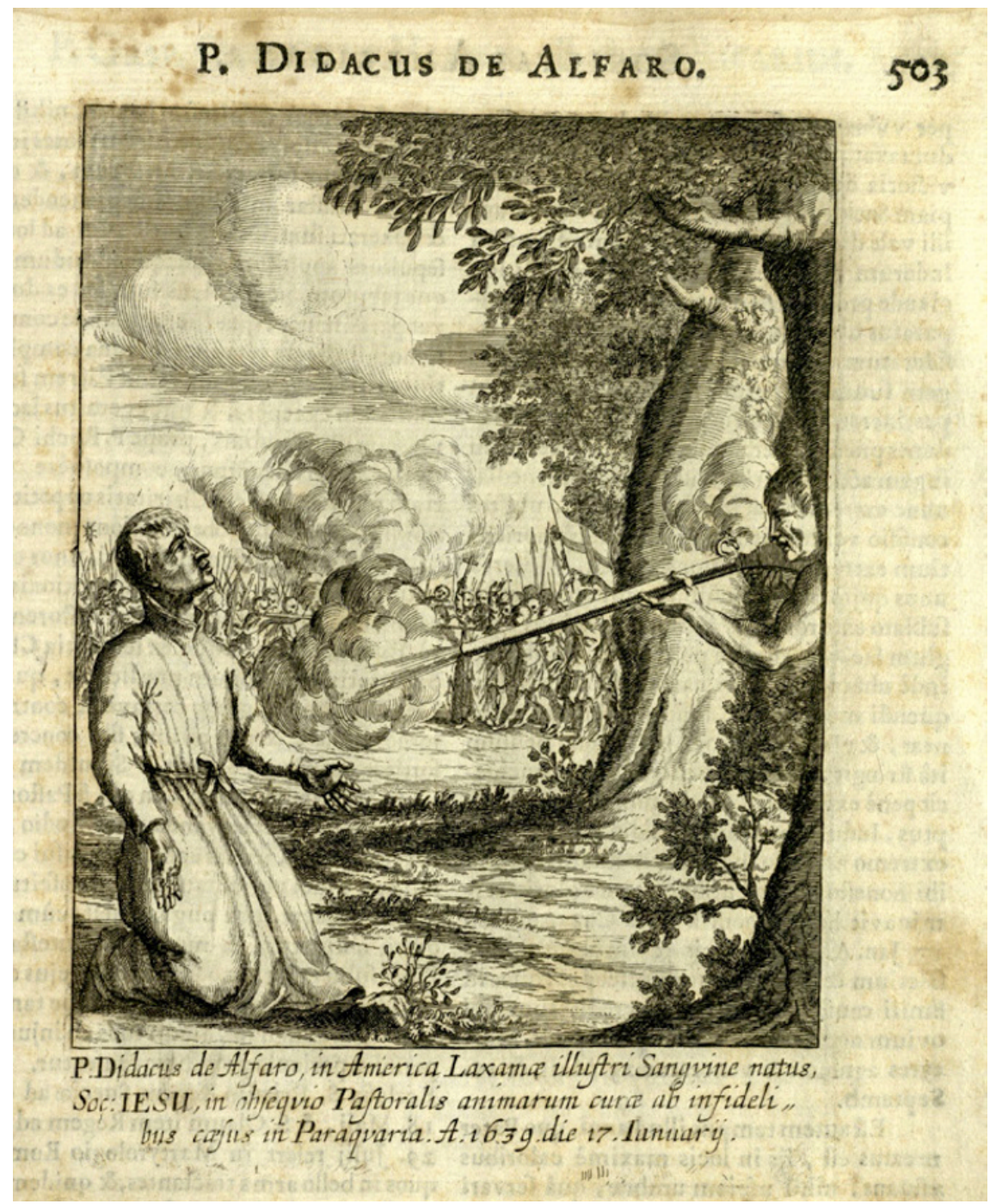

FIGURE 5.1 The Martyrdom of Diego de Alfaro

IN MATTHIAS TANNER, SOCIETAS JESU USQUE AD SANGUINIS ET VITAE PROFUSIONEM MILITANS (PRAGUE: 1675), 503. REPRODUCED WITH PERMISSION OF THE ARCHIVUM ROMANUM SOCIETATIS IESU

shall see, was no exception, even if he pushed beyond the boundaries of what might have been considered acceptable. The glory of God as manifested through justice and the salvation of the Guarani together with the common good - that of the defense of the people of God and the Catholic Churchform the backbone of his apologia. As such, while the content may arrive at remarkable conclusions, the letter itself is distinctively Jesuit. 
One still might legitimately ask the same about Alfaro's actions, however, in particular when the very constitutions of the Society insist on works of charity rather than violence. Furthermore, there were also precedents in relatively contemporary Hispanic and Lusophone history in which other clergy (nonJesuits) did take up arms, thus placing Alfaro's actions in a broader, non-Jesuit clerical tradition. A prime example of such a case would be the licenciado Pedro de la Gasca (d.1567), the royal commissioner sent by Charles I (d.1558, r.1516-56) to restore Peru to the crown after the rebellion of Gonzalo Pizarro (d.1548) in 1545. While Gasca's campaign was largely successful due to his astute negotiations and his willingness to compromise in order to draw less committed rebels over to the king's side rather than engaging in a series of pitched battles, he himself led the king's forces against Gonzalo Pizarro at the decisive battle in Jaquijahuana (Sacsahuana, Cuzco) on April 9, 1548, notwithstanding the fact that he had taken holy orders prior to entering the king's service. ${ }^{20}$ With this in mind, it could be argued that Alfaro's actions went against Jesuit norms while forming part of a much broader tradition of fighting clergy that goes back to the early medieval period; indeed, as we shall see, Boroa establishes a weighty lineage of ecclesiastical precedent in order to make precisely the point that Alfaro was by no means a clerical deviant. ${ }^{21} \mathrm{He}$ is similarly careful to ensure that this precedent is drawn from the actions of primarily non-Jesuit clergy in order to protect the Society from accusations that the Jesuits themselves are members of a subversive and violent order. Thus it might be suggested that Boroa's apologia itself demonstrates that Alfaro's actions are less Jesuit than they are part of the wider tradition of the church. As a counterpoint to this criticism, however, this chapter maintains that Alfaro's actions were distinctively Jesuit precisely because he was fighting for the just defense of his parishioners. This, as Boroa would argue, was how he put into action the Jesuit obligation to work for the glory of God and the common good. In so doing, he fulfilled his obligations as a Jesuit and a priest and died as a good shepherd defending his flock; as such, Boroa argued, in the manner of his death Alfaro became like Christ.

Pedro de la Gasca was acting under the express orders of Charles I to put an end to the rebellion in Peru, which he did. There is nothing in the historiography that appears to consider his actions (a priest under arms in contravention of canon law) controversial. Alfaro, by contrast, was not acting on the orders of the king and his actions were deemed controversial by the Society's enemies in Brazil and Paraguay. I am grateful to Gabriela Ramos for drawing my attention to this particular aspect of the chronology of Gasca's career.

21 Boroa, “Apología y defensorio, 18 Enero 1644," ARsi, Paraq. 11, fols. 263, 267r-269v. 
In 1639, in the frontier regions of Paraguay, circumstances had gone beyond mere representation and lobbying and required urgent action. According to Boroa, not only was Alfaro right to go into battle (contrary to the common interpretation of canon law) but he was effectively a martyr for justice. What is more, when it came to the question of homicide, he argued that not only would it be right to kill someone who oppresses the innocent, but that it would be a mortal sin not to do so. This was an argument that drew on scriptural precedent and Catholic eschatological and scholarly tradition and combined it with a graphic and detailed description of the contemporary reality in order to present highly controversial conclusions in a righteous call for action. What, one might ask, could be more Jesuit than this?

\section{Historical Context: The Jesuit Perspective}

Since the first mission foundation that the Jesuits made in 1609 through to the year 1632, the Jesuit province of Paraguay had undergone rapid expansion; during these years, more than twenty-one reductions had been founded. Nevertheless, from approximately 1620 , the Jesuit missions in the frontier regions bordering the rivers Uruguay and Paraguay (Guairá, Itatín, and Tape) had been the target of systematic and violent attacks from militia made up of Portuguese from São Paulo and their indigenous Tupi allies.

These raiders sacked the new missions with the prime objective of enslaving the mission populations. The Jesuit Ruiz de Montoya describes, for example, how: "their objective is to destroy the human race [...] They spend two or three years hunting men [and women] as if they were beasts."22 From the point of view of the bandeirantes, it was of course much more efficient to let the Jesuits do the work of founding the reductions and concentrating the Guarani into large towns. Once that was done, they could attack the missions when they were already populated instead of having to hunt the Guarani down in the forests, a task that was both arduous and dangerous.

For their part, the Jesuits of the province did not stand idly by while this was happening, and it is easy to see in their accounts a tremendous frustration at not being able to protect their neophytes even though they attempted various different strategies. They attempted to pressure the Spanish and Portuguese

\footnotetext{
22 Ruiz de Montoya, Conquista espiritual, cap. 35, fol. 45v. It is notable that he associates the Guarani with "the human race" and that he perceives the Portuguese attacks as so destructive that this immediately places them outside the human race and alongside the hosts of Lucifer who strive to destroy humanity.
} 
authorities and even lobbied Urban VIII to condemn these slaving expeditions, but they only managed to augment the violence against the Society and its missions. Three months after Alfaro's death (and as a result of extensive lobbying by the Society in Rome), Urban viII promulgated Commissum nobis (April 1639), reiterating the bull of Pope Paul III (r.1534-49), Sublimus Deus, promulgated in 1537, that forbade the enslavement of indigenous Americans, and specifically intended it for the regions of Brazil, La Plata, and Paraguay. His language was strong, insisting that "no-one dare or presume to reduce the Indians to slavery, sell them, purchase them, exchange them or give them away, separate them from their wives and children, despoil them of their belongings and goods, move them to other places and displace them, or deprive them of their freedom in any manner whatsoever." All those who continued to take part in slaving expeditions were to be excommunicated. ${ }^{23}$ Nevertheless, we read in Boroa's apologia that when the Jesuits in São Paulo published the bull in 1640:

In a mob they [the citizens of São Paulo] rioted in hatred of the apostolic bull and attacked our college [...] and in a rage they hacked at the doors $[\ldots]$ with machetes and axes, striking many blows at a bronze Jesus [...] in hatred of the pope $[\ldots]$ and of his bull $[\ldots]$. They talked as if they were heretics, saying that if [the pope] were to come there they would hang him for having promulgated that bull [...] and they would throw out the members of the Society and their schools just like they had done in Holland and England, and attacking with great fury and alarm, the soldiers gathered [...] and with a large army made up of all of them, together with their false Tupis, and true captives of our reductions, they attacked [the missions] last March with the intention of destroying everything. ${ }^{24}$

Nearly a decade earlier, in 1631 , the Society ordered a disastrous relocation of those missions that remained close to the frontier. ${ }^{25}$ As Ruiz de Montoya himself writes: "Famine, disease and the variety of opinions caused a tremendous confusion: because how would there not be hunger among such an immense

23 Cited in Gustavo Gutiérrez, Las Casas: In Search of the Poor of Jesus Christ (New York: Orbis, 1993), 311-12; Hans-Jürgen Prien, Christianity in Latin America, trans. Stephen Buckwalter (Leiden: Brill, 2013), 163.

24 Boroa, "Apología y defensorio," fols. 269r-v.

25 James Schofield Saeger, "Warfare, Reorganisation and Readaptation at the Margins of Spanish Rule: The Chaco and Paraguay (1573-1882)," in The Cambridge History of the Native Peoples of the Americas, vol. 3: South America, part 2, ed. Frank Salomon and Stuart Schwartz (Cambridge: Cambridge University Press, 1999), 275. 
gathering of youngsters and adults, who on that journey could only carry a limited amount of food on their shoulders and backs for want of any other help? And, how would there not be disease among such necessity when merely the thought that they were running out of provisions caused hunger and, as a result, disease?"26 In fact, Ruiz de Montoya's order provoked rebellions in reductions such as San Cosme, Natividad, Santa Ana, San Damián, San José, and San Nicolás on the part of Guarani neophytes whose enthusiasm for the missions was only lukewarm and was waning fast. ${ }^{27}$ The result was the flight and deaths of many thousands of Guarani en route. Of the twelve thousand or so Guarani who underwent the forced march, only four thousand managed to arrive at the areas chosen for relocation. ${ }^{28}$ Those who fled could be hunted down by the bandeirantes. Those who survived had left their ancestral lands and had to integrate into lands already occupied by other ethnic groups, potentially causing or exacerbating tensions. Yet, as the Jesuits saw it, what other options remained? Even though the Guarani were themselves warriors, for the first twenty years of suffering these assaults they were unable to defend themselves adequately against the relatively massive attacks of the Portuguese who used firearms, and their Tupi allies, who fought with traditional bow and arrows.

All those involved knew that this was key. Throughout this period of turbulence, the Society had been petitioning the Council of the Indies and successive viceroys in Lima to allow the Guarani to form militias that could be trained in the use of firearms. In 1637, Ruiz de Montoya was sent to lobby Philip IV for such a solution. His representation to the court met with success in May 1640 when the monarch signed the decree permitting the use of firearms. ${ }^{29}$ Yet, such a move had met substantial opposition from secular authorities and colonists in Paraguay and La Plata and also in the court itself, concerned about the implications of semi-autonomous standing indigenous armies trained in modern

26 Ruiz de Montoya, Conquista espiritual, cap. 38 , fol. $48 \mathrm{v}$. He describes the exodus from the missions of Loreto and San Ignacio in chapters $38-39$ (fols. $48 \mathrm{v}-53 \mathrm{v}$ ).

27 Branislava Súsnik and Miguel Chase-Sardi, Los indios del Paraguay (Madrid: Editorial MAPFRE, 1995), 20; Ernesto Maeder, "La población de las misiones de guaraníes (16411682): Reubicación de los pueblos y consecuencias demográficas," Estudos IberoAmericanos 15, no. 1 (1989): 49-80, here 52. According to Maeder, the Jesuits closed all debate by ordering the burning of the villages as they left-a drastic measure aimed at pronouncing the finality of the decision to relocate.

28 Alberto Armani, Ciudad de Diosy ciudad del sol; El "estado" jesuita de los guaraníes (1609-1768), (México, DF: Fondo de Cultura Económica, 1982), 8o. See also, Barbara Ganson, The Guarani under Spanish Rule in the Río de la Plata (Stanford: Stanford University Press, 2005), 46. The sources do not record how many refused to locate as opposed to those who died en route.

McNaspy, "Introduction," in McNaspy et al., Spiritual Conquest, 18. 
warfare and which would vastly outnumber Spanish militia from the region. As a result, the king deferred his decision to the authority of the viceroy in Lima, Pedro de Toledo y Leiva. The situation was so desperate in the missions, meanwhile, that they could not wait for the arrival of such a controversial license, should the viceroy even deem it expedient. ${ }^{30}$ As a result, the Guarani and the Jesuits seized the initiative and beat the Portuguese in 1641 at the Battle of Mbororé after gathering together a large army capable of using a variety of weapons, including firearms s. ${ }^{31}$ Overall command of the Guarani mission forces was in the hands of the powerful cacique (indigenous leader) Don Nicolás Ñeengirú, but his captain was the Jesuit coadjutor and ex-soldier Domingo Torres. ${ }^{32}$

The Guarani victory at Mbororé in 1641 nevertheless took place after the death of Alfaro-January 1639-which for the Jesuits and the mission populations was arguably the nadir of the conflict. By the time Alfaro was killed, according to the Jesuit letters and the chronicle of Ruiz de Montoya, thousands of mission Guarani had been taken as slaves or killed, towns had been sacked and burned, churches and sacred images had been profaned, and the "City of God" that the Jesuits had tried to institute on the Paraguayan frontier appeared to be on the verge of annihilation.

\section{Jesuits and Salvation: An Eschatological Context}

In the letters and the polemics of the Jesuits who depict the successive invasions of the missions by the bandeirantes of São Paulo, it is quite clear how a

30 Approval was finally granted (or at least acknowledged as a fait accompli) by the viceroy García Sarmiento de Sotomayor in 1649.

31 Mercedes Avellaneda and Lía Quarleri, “Las milicias guaraníes en el Paraguay y Río de la Plata: Alcances y limitaciones (1649-1756)," Estudos Ibero-Americanos 33, no. 1 (2007): 111. Saeger writes that the viceroy "had given the King the necessary assurances that let the men of the missions carry firearms" by 1646 (Saeger, "Warfare, Reorganisation and Readaptation," 275). Armani, Ciudad de Dios, 85. Ganson incorrectly identifies Torres as a Jesuit priest (Guarani under Spanish Rule, 46). That he was a lay coadjutor can be verified in Josephus Fejér, Defuncti secundi saeculi Societatis Jesu, 1641-1740 (Rome: IHSI, 1990), 5:S-Z, 202 (http:// www.sjweb.info/arsi/Digital_Repertory.cfm). Torres died in Apóstoles in August 1688. In 1628 , after the killing of three Jesuits in an indigenous uprising, Ñeengirú, the most powerful cacique in the missions, led the mission forces to suppress it. Pedro Romero(?), "16281629, Relacion del Glorioso Martyrio [...]," ARSI, Paraq. 11, fols. 172r-179v, fols. $176 \mathrm{r}-\mathrm{v}$ (the letter is unsigned but was written by the superior of the mission of Candelaria, who at the time was Pedro Romero). 
distinctive form of Jesuit spirituality influences their way of seeing these events and, of course, their subsequent choices. They leave no doubt in the minds of their readers that these were infernal attacks instigated by the antichrist and carried out by his hosts - the Portuguese. In 1628, Boroa, then rector of the College of Asunción, asserted this explicitly in a letter to Muzio Vitelleschi: "I have described to you, my Father, the terrible persecution that the Devil and his ministers have stirred up in various ways against the missions of Paraguaythis new plant of the Lord."33

There are numerous other examples in which the Jesuits of Paraguay depict the Portuguese as instruments of the devil. Ruiz de Montoya, for example, summarizes his own arguments in the chronicle, The Spiritual Conquest, by writing:

In the second section it describes the precaution that more than twenty years ago the Divine Majesty took in sending [Jesuits] to the Province of Guairá so that the predestined might be gathered up before the Antichrist could disturb them; and there I noted the signs. The demons that I described in section sixteen explained this and they appeared in their customs to be very similar to those from São Paulo and the coast of Brazil, taking their form with their shotguns and weapons. And they even said they were their friends. ${ }^{34}$

According to his summary, when demons appeared to the people of the missions, they took on forms identical to the bandeirantes of São Paulo, admitting to being their friends. Of course, this might easily be interpreted from a modern secular perspective as the appearance of scouts from larger raiding parties attempting to turn the people of Guairá to their side and against the Jesuit mission organization. Such an interpretation would certainly add complexity to the narrative of relentless Portuguese attacks on the reductions; these demons then were not mimicking the Portuguese and taking on their form, they actually were the Portuguese. As might be expected on a typical frontier society, there was space for negotiation and for alliances to shift between opposing sides. ${ }^{35}$ Nevertheless, such an interpretation can and should be reread from the perspective of the Jesuits and the many thousands of mission Guarani who remained loyal to the Society of Jesus. These individuals who

\footnotetext{
33 Boroa, "Relacion de la persecucion," fol. 123r.

34 Ruiz de Montoya, Conquista espiritual, cap. 74, fol. 9ir.

35 This is borne out by a point Ruiz de Montoya makes in his chronicle when he describes the siege of Villarrica. Ruiz de Montoya, Conquista espiritual, cap. 37, fol. 48r.
} 
appeared in the midst of the indigenous inhabitants of Guairá may have taken human form - that of the Paulistas - but their false promises that led to the destruction of the Guarani communities in the region betrayed their demonic nature. Ultimately, the Paulistas and the hordes of Satan were part of the same faction - that of the antichrist. Without a doubt, from the perspective of the Jesuits-due to their Ignatian (and, in this respect, one might argue Augustinian) spirituality, which facilitated their seeing the world divided eschatologically-the attacks on the missions that the Portuguese were carrying out in the frontier region of Guairá were part of the same quasi-eternal struggle the devil was leading with his hosts against the City of God and, in the Exercises of Saint Ignatius, against all the cities and individuals of the world. The meditation on the two standards for the fourth day of the second week is demonstrative of this point, as it encourages the practitioner to

imagine the leader of all the enemy in that great plain of Babylon. He is seated on a throne of fire and smoke, in aspect horrible and terrifying. Consider how he summons uncountable devils, disperses some to one city and others to another, and thus throughout the whole world, without missing any provinces, places, states, or individual persons. ${ }^{36}$

In actual fact, it was not even necessary to state explicitly on whose side the Paulistas were fighting in this total war between the armies of the devil and Christ; all the Jesuits had to do was describe the atrocities they were committing against the Guarani and the acts of sacrilege they were carrying out against the church for readers (whether they be Jesuit superiors in Rome, the king, or his councilors and dignitaries) to be quite clear about what was happening. The attackers were so degenerate (according to how they were described) that not even the presence of the Blessed Sacrament calmed their fury. Ruiz de Montoya explains:

Not just in this reduction but in others, the Fathers asked me to expose [Our] Lord [the Blessed Sacrament] with every reverence and place Him at the entrance of the church to impede their entry. "Do you want," I said, "to give these heretics the opportunity to seize the Blessed Sacrament and throw it to the ground in front of our eyes before trampling and burning it?" And so it was necessary to consume it and take it down from the

$36 \quad$ Ignatius of Loyola, The Spiritual Exercises of Saint Ignatius, trans. and ed. George E. Ganss (Chicago: Loyola Press, 1992), 65-66. 
Altar where it was venerated by people who yesterday [very recently] were pagan infidels. ${ }^{37}$

Ruiz de Montoya knew that exposing the Blessed Sacrament would have no other effect than giving rise to the worst possible sacrilege. The previous destruction of other missions assured him this would be the case. For example, when the Portuguese fell on the reduction of Jesús María on the Feast of Saint Francis Xavier (1637):

The enemy decided to burn the church; I confess that I have heard it said that they are Christian, and even on this occasion they carried Rosary beads quite correctly. Without doubt they have faith in God [but] their deeds are of the devil [my italics]. ${ }^{38}$

While the people who had taken refuge inside the church building screamed in fear, the Portuguese celebrated that the building had caught fire. The desperate people inside decided to risk coming out so as not to die roasted in the flames and so:

They made a small opening and came out in the same way that sheep leave their pen to graze. As if possessed, those fierce tigers gathered around the opening and with swords, machetes and scimitars ${ }^{39}$ they cut off heads, lopped off arms, sliced off legs, pierced bodies through, killing with the most barbarous fury that the world has ever seen. [...] They tested the steel of their scimitars by slicing children in two, splitting their heads open and chopping up their delicate limbs. The shouts, yells, and howls of these wolves, together with the piteous cries of pain of the mothers on seeing their children chopped up and who [themselves] were run through by the barbarous swords caused a horrendous confusion. ${ }^{40}$

One might accuse Ruiz de Montoya of exaggerating the horror of the event for rhetorical effect, and certainly detractors of the Jesuits did not hold back from

\footnotetext{
37 Ruiz de Montoya, Conquista espiritual, cap. 35, fol. 46r.

38 Ibid., cap. 75, fol. 93r.

39 Ruiz de Montoya uses the term alfanje which translates as "cutlass" or "scimitar." Given that he was portraying the Paulistas as enemies of God, and that another term to refer to them was "mamelucos," "scimitar" seems to be the appropriate rendition as the descriptive imagery links the Paulistas to the Turks, supposed enemies of Christianity par excellence.

Ruiz de Montoya, Conquista espiritual, cap. 75, fol. 93r.
} 
making this type of accusation. In 1638, both the governor of Paraguay, for example, Pedro de Lugo y Navarra (1634-41) and the cabildo (town council) of Asunción had written to Philip IV accusing the Jesuits of falsely representing the success of the conversion of the Guarani and petitioning him not to allow them to be armed as they might turn on the Spanish colonists; the Jesuits, for their part, were locked in dispute with Lugo y Navarra who bitterly opposed their proposals for the defense of the missions and arming of the Guarani militia. ${ }^{41}$ Following the death of Alfaro, meanwhile, Boroa took Lugo y Navarra to task for refusing to punish Alfaro's Paulista killers, who had been captured by Don Nicolás Ñeengirú and handed over to the governor. This refusal to punish the Portuguese, he said, "caused scandal among the Indians." 4 Thus, there was no love lost between the Society of Jesus and the secular Spanish authorities in Paraguay, and Jesuit accounts of the scale and horror of the bandeirante attacks were contested at every stage: what sense did it make for the Portuguese to kill those who they were originally intending to enslave? A modern reading of these accounts might also tend towards skepticism, albeit perhaps less cynical; after all, members of the Society of Jesus were renowned for their mastery of rhetoric, both in oratory and writing. Yet, a reader should also take into account that these massacres formed part of a specific strategy of war in order to achieve a number of ends. In the first instance, their goal was to terrorize the population so that they did not resist (and the reduction of Jesús María had resisted). Second, such tactics were designed to eliminate those captives who (for them) had no value - that is to say, those who were too young, too old, or sick, and who could not be marched to São Paulo or who could not work. Third, they intended to persuade the population not to trust the Jesuits (who bitterly opposed the Paulista policy of enslaving indigenous people) by demonstrating that these priests were utterly powerless to protect them. Fourth, the brutality of these attacks was designed to terrorize the surviving captives so that they did not flee.

Despite the fact that, for the Paulistas, at that moment in time and in that region there was a surplus of people to enslave, the massive destruction of the region which included three Spanish towns (Villarrica, Guairá, and Jeréz) ${ }^{43}$

\footnotetext{
41 Adalberto López, The Colonial History of Paraguay: The Revolt of the Comuneros, 1721-1735 (New Brunswick: Transaction, 2005), 42.

42 Boroa, "Apología y defensorio," fol. 266r.

43 Ruiz de Montoya, Conquista espiritual, caps. 37-38, fols. 48r-5or. López states that by 1631 the Spanish towns of Villarrica and Ciudad Real had been destroyed (López, Colonial History of Paraguay, 35). Ciudad Real refers to Ciudad Real de Guayrá; Jeréz refers to Santiago de Jeréz in Itatín.
} 
also indicates that this was an expansionist conflict in which the Portuguese were stamping their new dominion on the survivors through terror. In fact, the atrocities the Jesuits recounted (and in particular those that can be read in the chronicle of Ruiz de Montoya) bear a marked resemblance to testimonies given by survivors of various dirty wars that were carried out primarily against rural populations in numerous Latin American states during the twentieth century.

As an example, to demonstrate the plausibility of the Jesuit accounts one can compare the testimony of a young girl who survived an attack by the same group of bandeirantes who assaulted the reduction of Jesús María with others from twentieth-century conflicts. Given the importance of the details included in the testimony, it is worth quoting in full:

Father Diego de Boroa, our Provincial, wanted to talk to the enemy-as if they were capable of reason-[and] a few of us priests accompanied him. In San Cristóbal we found twenty dead bodies with cruel machete wounds and bullet wounds. We delayed to bury them. We found a pagan girl of about seven years old wandering lost through those woods. She had two cruel wounds; one was very long and had been cut across her face, the other was on her head. Both [wounds] were covered in maggots. She recounted her disastrous story to us as follows: "I was with my parents and their children. These men suddenly attacked our houses. They divided us up between them, and another took me and a younger brother of mine, and seeing we were orphans, slaves, the two of us escaped to try to find you [the Jesuits] so that as our Fathers you could protect us; [but] they tracked us and in a terrible rage they gave me these wounds and another to my brother on his neck leaving him unable to move his head, and then they left us for dead. I came to and saw that my brother was still alive. Terrified I fled into the forest carrying my little brother in my arms. I was with him for three days, without eating or drinking, keeping going with the hope that when he came to we could carry on our journey. But seeing that he was dying and I was as you see me, I left him still alive. Wracked with pain I tried to carry him on my back and I couldn't." We healed her body and then her soul with baptism. Everywhere we trod there were dead bodies, decapitated, pierced with arrows and hacked to death. ${ }^{44}$

While it is clear that the precise words of the girl's account have been edited in the retelling by the Jesuits, and possibly even added to (such as the section 
where the children seek out the Jesuits specifically for protection rather than simply fleeing their captors when they saw the chance), the stark and shocking plausibility of this account is revealed by comparing it to testimonies from recent genocidal civil wars such as that which occurred in Guatemala between 1977 and 1996:

I was playing there when I saw the soldiers coming up. As they came, my mom told me to run. Since my dad's house had two doors, one in front and the other leading out among the coffee bushes, I fled; I knew that they had already started killing. I ran alone among the coffee bushes, and my mother did not follow me. At about four o'clock in the afternoon, I went back to the village. They had already burned the house and my family. No one was left. [Case 10066 (massacre), Aldea Kajchiljlaj, Chajul, Quiché, 1982]

Because the truth is, so many innocent children died! They didn't even know why this happened. The truth is, when you went to places like that, you saw dead people all over. They left them all cut up, an arm here, a leg there; that's how it was. [Case 3024, Aldea Panacal, Rabinal, Baja Verapaz, $1981]^{45}$

The point here is not to reduce all conflicts to the same explanation or cause, but rather to demonstrate with such recent examples that in the context of a conflict in which generalized terror is used as a strategic weapon, and in which the testimonies of the surviving victims are documented as truth and as part of institutional Truth Commissions, these Jesuit descriptions from seventeenthcentury Paraguay are inherently plausible and, alongside such recent comparative examples, do not appear at all exaggerated. By the same token, one comment by Ruiz de Montoya describing what the Jesuit party witnessed as it passed through a nearby village on returning to the reduction of Jesús María to bury the dead is spectacularly striking for what it says about the strategy of the aggressors to wipe out even the memory of what went before their attack. This too has been a significant part of the ideological struggles so symptomatic of the dirty wars of the twentieth century:

45 Rem Hi, Guatemala, Never Again: Recovery of Historical Memory Project: The Official Report of the Human Rights Office, Archdiocese of Guatemala (Maryknoll, NY: Orbis, 1999), 32-35. For an academic study of this genocide, see in particular Victoria Sanford, Buried Secrets: Truth and Human Rights in Guatemala (New York: Palgrave Macmillan, 2003). 
Here we found rational people burned alive: children, women, and men. We saw one woman burned with two twins who were burned with her in her arms. A common strategy of these murderers when they leave with their prisoners is to burn the sick, the old and those who cannot walk: because if any remain alive, those who go return to the memory of those who stay [my italics].46

According to this stratagem, then, not one trace of the past could survive so that the new slaves had nothing to which they might return. It was a total war of absolute domination in which all traces of the past existence of the indigenous populations of Guairá must be erased so that they had no choice but to accept their new condition of slavery. From the perspective of the Jesuits, it was waged against the people of God, and by extension, the church, and for this reason it was all the more perverse. Worse still, at this moment in time, it seemed that the hosts of the devil of São Paulo were winning. In 1629, Father Justo Mancilla van Surque wrote to Rome, practically despairing of the situation, saying: "We turn to you [my Father], given your zeal for the honor of God [and] of the salvation of souls so appropriate to our Society, [and beg] that you find us some solution as quickly as possible, because here there is none."47 It seemed there was no remedy to this desperate situation and the salvation of the souls of the indigenous populations was in grave danger. Yet what more could the Jesuits do? It was no longer sufficient to beg for help from the authorities, although they continued to do so. According to a letter written by Boroa in 1631, Father Diego de Torres, provincial of Paraguay in 1607-15 "has written to us many times [...] encouraging us to suffer for such a just cause as it is and has been, to defend these poor, defenseless Indians." ${ }^{48}$

However, the question might be asked, what exactly did the term "defend" mean? Given that this unjust war against the Guarani was continually escalating and that all the measures the Jesuits had tried thus far had failed, it had become necessary to take their physical defense seriously. According to the thought of the Jesuit Scholastic, professor of theology, and near contemporary to the Paraguayan missionaries, Francisco Suárez, "whoever begins a war without just cause sins not only against charity, but also against justice; and hence he is bound to make reparation for all the harm that results. The truth of this

\footnotetext{
46 Ruiz de Montoya, Conquista espiritual, cap. 77, fol. 95v.

47 Mancilla van Surque, “Octub 2 de 1629," fol. 224r.

48 Boroa, "Relacion de la persecucion" ARsi, Paraq. 11, fol. 123r.
} 
conclusion is manifest."49 So, there was a need to draw a line in the sand and use all possible means to combat these demonic hosts and defend the defenseless. ${ }^{50}$ The Paulistas were fighting perversely for injustice, while the City of God, on the other hand, needed to battle for justice. ${ }^{51}$ Not surprisingly, in this context of total war, the resistance of the mission populations against their persecutors increased, as we read in Ruiz de Montoya's account of the attack on the reduction of Jesús María:

Two priests and two of our brothers were there and on seeing themselves caught in the midst of flying bullets, the brothers and Indians dedicated themselves to the just defense of the mission and the fathers to encouraging them. They fought for six hours, from eight in the morning until two in the afternoon. ${ }^{52}$

Ruiz de Montoya is careful here to distinguish the activities of the brother coadjutors from the priests as he would have been well aware of the canonical prohibition on priests taking up arms. It must be remembered that he was writing this chronicle as part of his campaign in the Spanish court and in the context of a bitter dispute. He had to take every care not to give away information that could be used against the Society and against the common good of the mission populations. By contrast, the problem of brothers of a religious

49 Francisco Suárez, "The Three Theological Virtues: On Charity; Disputation XIII: On War," in Williams et al., Selections from Three Works of Francisco Suárez, 8oo-65, Section 4:8, 820. Even this seemingly emphatic statement is somewhat ambiguous. If someone starts an unjust war and then makes reparations, does that absolve them of their responsibility for the sin? If so, arguably this might permit people to wage unjust wars for personal gain as long as they have the intention of making reparations at some point in the future.

5o The notion that the Guarani were defenseless was the Jesuit discourse. They were not defenseless and needed no encouragement to fight, but in these early years the odds against them were overwhelming. Relatively speaking, then, the Jesuit discourse was true.

$5^{1}$ A note of caution is necessary here. According to João Fernandes, the Jesuit theorist Luis Molina defined "justice" more narrowly than might be done today, as something that had to do with "the acquisition and loss of property" and the "violent change in the order of property” (Fernandes, "Luis de Molina: On War," 95). Suárez's call for restitution suggests a similar definition, but Suárez also positions the sin of an "unjust war" as both sin against charity and justice, thus moving towards the broader definition of "justice" that might be applied today. Boroa's use of "justice" and "unjust" also seems to be broader and more attune to our modern understanding of these terms with respect to the deprivation of rights. In Boroa's understanding, these would be considered "natural" rights as part of the "natural law."

Ruiz de Montoya, Conquista espiritual, cap. 75, fol. 92v-93r. 
order taking up arms was more open to interpretation. Suárez, for example, when considering this same issue, wrote that "it is forbidden under the gravest penalties and censures [that clerics should engage in war]. [...] As to others, however, constituted in minor orders, since they participate but imperfectly in the clerical state, it is probable [...] that they are in no way bound." ${ }^{53}$ Thus, brother coadjutors might in all probability (according to Suárez) not be bound by the canonical prohibitions on fighting, and if coadjutors could and were now fighting side by side with the Guarani populations of the missions, and the priests were encouraging them, arguably this was but a few steps away from the moment in which a priest-following the clear obligation to combat evil as a soldier of Christ - took up arms and joined in the defense of his people. This is precisely what we read in Boroa's letter to the superior general in Rome defending the actions of Alfaro after he was killed by the Portuguese:

I write to you, [my Father], this letter or apologia about the blessed death of Father Diego de Alfaro [margin note: died January 14, 1639] [...] who died as a good shepherd in defense of his flock, [...] with the greatest and most heroic act of charity, as Christ Our Lord teaches us, giving his life for his sheep for the salvation of whom he [Alfaro] willingly offered himself in true sacrifice to the divine majesty, shedding his blood out of love in imitation of [Christ], who as God, shed it for them [Christ's flock]. ${ }^{54}$

Immediately, Boroa names Alfaro a good shepherd, of the kind described in the Gospel of John, who defends his sheep from the wolves even if this costs him his life. ${ }^{55}$ According to the Gospel, it is Jesus who self-sacrifices to defend his sheep. Thus, Alfaro, according to the apologetic discourse of Boroa, died in imitatio Christi, fulfilling the duty that Jesus had left to his followers. Of course, the paradoxical argument that equated the actions of a soldier in war with Christ's unresisting sacrifice would not be lost on his readers. The scriptural passage in which Jesus heals the ear of the high priest's servant in the Garden of Gethsemane after it had been cut off by one of his disciples was a clear counterpoint to such an argument. Jesus even told the disciple to put the sword away and that he who lived by the sword would die by it. ${ }^{56}$ Nevertheless, John

53 Suárez, "The Three Theological Virtues: On Charity; Disputation XıII: On War," 80o$65:\{3: 5,812$. He cites other Scholastic theologians and philosophers as authorities on these points.

55 John 10:11-18.

$5^{6}$ Matt. 26:52. 
10:11-18 is also explicit in its counsel: the good shepherd should defend his flock from the wolves even if he might be killed in the process. There is an unresolved scriptural tension here that Boroa deals with by focusing on the latter and ignoring the former while turning the reader's attention to the virtue of charity that obliged a priest to fight against an injustice that endangered the souls of his flock, the Guarani of the missions.

This point is worthy of further scrutiny. According to this reasoning, the unjust captivity and killing of the Guarani (together with the sacrilegious destruction of the mission churches and of religious objects), aside from being a mortal sin that all Christians should oppose, meant that those captured would neither receive sacraments nor catechesis. This placed their very souls in mortal danger, especially when they were in danger of death. The Jesuit testimonies describe how the Paulistas, out of hatred for the Society, did not permit the Jesuits to administer the sacraments, not even to those who were dying. For this reason, we read in Boroa's letter that

it is certain that the Portuguese of Saint Paul and the Saints [São Paulo] not only impede the Indians that they unjustly capture from receiving the Blessed Sacraments, but of twenty or thirty thousand that they ordinarily capture in one of these raids, more or less three quarters die: the pagans without baptism and the Christians with neither confession, nor any other Sacrament. They take many of these lives with their steel [swords] through inhuman cruelty, and the rest [die] as a result of mistreatment [and] they leave the forests and countryside strewn with dead bodies. And even those who survive given the large numbers that they take, on arriving in Brazil they either die of hunger, of excessive work, or of sadness on seeing themselves captive in a foreign land, many of them deprived of their wives and children without parents, without churches and Sacraments as the very same Portuguese certify. And this was proven before his Catholic Majesty [the king] as his royal proclamation of [16 $]_{39}$ declares. ${ }^{57}$

This injustice, against which the rigors of charity obliged the Jesuits to fight, did not therefore merely embody a temporal injustice that caused suffering, pain, and poverty (caused without doubt by the sins of the Paulista slavers); rather it was an eternal injustice that endangered the salvation of the innocent, depriving them of the necessary measures to be saved and undoing everything that had been done to place them on the path to divine glory. Even 
worse, it was increasing the probability that they would die either before receiving baptism or in a state of sin, either of which would render their salvation impossible. Faced with such a tremendous injustice, what should a Jesuit priest do? He could either "keep quiet and cry," as the Jesuit priest Simón Maceta explained after he tried to intercede for a Guarani cacique who had been captured and merely worsened the situation, ${ }^{58}$ or he could do what Alfaro did and take up a weapon and fight to the death: "encouraging the Indians to the natural defense of themselves, their wives and children, of their churches, and of the faith and good customs." ${ }^{\text {9 }}$

\section{Jesuit Thought and Conscience: Casuistry, Violence, and Martyrdom}

The apologetic letter of Diego de Boroa exemplified contemporary Jesuit thought by establishing that resistance to injustice (and not just pacific but also armed resistance) necessarily became a weight on the Christian conscience. Furthermore, if the Christian had an obligation to fight for good, from the perspective of the Jesuits of Paraguay, the priest himself needed to fight to defend his spiritual charges. In other words, Boroa, speaking for the Jesuits of his province, inverted the discourses of those who were scandalized by the fact that a priest had been killed in the midst of a battle in order to put forward an argument which demonstrated to the contrary, that first it was a scandal if a priest did not fight and, secondly, that such righteous violence formed part of the salvific spirituality of the Society. ${ }^{60}$

Before continuing with Boroa's 1644 apologia, it is useful to glance briefly at a letter he wrote nearly two decades earlier in 1620 in which the reader can see the sense of obligation he felt towards the Guarani. In it, he explains that

by leaving their lands, their fields and whatever else they had, trusting in the [Jesuit] Fathers they [the Guarani] surrendered themselves and their

$5^{8}$ Instead of ameliorating the situation, Maceta's intercession provoked the summary execution of the cacique along with other victims who had invoked the names of the priests for protection. Simón Maceta, "Deste Colegio dela Bahia, y 3 de octubre de 1629," fol. 225 r. Boroa, "Apología y defensorio," fol. 263 r.

6o Readers may be interested to compare this casuistic defense of Alfaro with parallel cases of equivocation by missionaries in southeast Asia in order to work around canonical prohibitions on missionaries acting as healers and medical doctors. See Tara Alberts, Conflict and Conversion: Catholicism in Southeast Asia (Oxford: Oxford University Press, 2014), $113^{-19}$. 
children completely in order to be taught the law of God and be saved. They gathered in large townships where they had beautiful churches, music and Christian virtue, and frequent access to the sacraments [my italics]. ${ }^{61}$

The phrase that the Guarani "surrendered themselves [...] completely" and trusted in the Jesuits' word to permit themselves to be gathered (lit. reduced) into Jesuit missions deserves emphasis. Of course, we know that the reality was very different, because the Guarani had diverse reasons to accept or reject the proposition to relocate to the Jesuit reductions; indeed, the deaths of three Jesuit priests in 1628 during an indigenous uprising in the new mission territories of the Caaró and the subsequent conflict between the mission Guarani and their non-Christian relatives are testament to the complexity of this process. ${ }^{62}$ Nevertheless, one can still see here the perception of the Jesuits that the Guarani as a people had clearly taken a step on the path towards salvation, but that the consequence of that decision, by contrast, had caused them horrendous suffering (as a result of the demonic actions of the Portuguese) in both this life and the next. Although this early letter does not say it explicitly, the obligation of these priests was to avoid at all costs the damnation of these people who had placed their trust in the care of the Society of Jesus. This sense of responsibility endures throughout Boroa's career and is carried forward into his apologia of 1644 in which he loses no time in launching his polemic by proclaiming that "[Alfaro's] glory is neither diminished by his detractors nor by those of the Society who seek to tarnish it by saying that he was killed by a bullet while fighting with a shotgun captaining the Indians." 63

The gossip of the Spaniards and Portuguese was not important. Despite the fact that Boroa initiated his discourse by attempting to blur the certainty around the facts - stating that Alfaro was not actually fighting, but that he was just using his weapon to encourage the Guarani to defend themselves as was

\footnotetext{
61 Boroa, "Relacion de la persecucion" fol. 123r.

62 The priests (proclaimed martyrs immediately by the Society and canonized in 1988) were Roque González, Alonso Rodríguez, and Juan del Castillo. See, in particular, Michael W. Mathes, ed., Primeras noticias de los protomártires de Paraquaria: La historia panegírica de Juan Eusebio Nieremberg. León Francia: 1631 (Santo Tomé, Baja California: Casa de la Cultura "Concepción Centeno de Navajas," Carem, 2004). See also José María Blanco, Historia documentada de la vida y gloriosa muerte de los padres Roque González de Santa Cruz, Alonso Rodríguez y Juan del Castillo, de la Compañía de Jesús, mártires del Caaró e Yjuhí (Buenos Aires: Sebastián de Amorrortu, 1929).

63 Boroa, "Apología y defensorio," fol. 263r.
} 
their natural right ${ }^{64}$ - the focus of his argument was not so much to deny that he fired his weapon; that much was conceded. Instead, the former Jesuit provincial immediately moved to an argument that essentially said it was not important that people were saying Alfaro died while fighting under arms because, even if he did, what he was being accused of was merely doing his priestly duty.

Boroa began by citing a powerful array of theologians like Archbishop Diego de Covarrubias, Martin Bonacina, ${ }^{65}$ his Jesuit contemporary Leonard Lessius, and his near contemporaries Molina and Suárez (all of whom published academic treatises discussing the legality and morality of warfare in a context of providing Scholastic, casuistic, and theological council to authorities who may need to make the difficult decision to go to war or use violence). He wrote:

It is plain to see, as Covarrubias, Lessius, Suárez, Bonac[ina], and Molina, and others prove at great length, that it is licit, just and holy to kill someone who attacks the innocent, defending him or her when there is no other means to do so without the cleric incurring irregularity [my italics]. ${ }^{66}$

Boroa thrusts directly to the heart of the polemic. To this first declaration, he adds another, proclaiming:

This is not just licit and just, rather, it would be obligatory and a mortal sin not to do it if one can. All this occurred in the present case of Father Diego de Alfaro, [given that] this obligation is all the more pressing for parish priests [my italics]. ${ }^{67}$

64 This claim may shed some light onto Ruiz de Montoya's assertion that the priests of Jesús María limited themselves to "encouraging" the defense of the mission (see above).

65 The letter cites a theologian named "Bonac." This is most likely to be Martino Bonacina, who, according to the Universal Biography was "an ecclesiastic of Milan in the service of Urban vili [who] died in 1631" (William A. Beckett, A Universal Biography: Including Scriptural, Classical, and Mythological Memoirs, 3 vols. [London: W. Lewis, 1836], 1:486).

66 Boroa, "Apología y defensorio," fol. 263r. Boroa cites these Scholastic theologians who, in turn, keep the writings of St. Thomas Aquinas at their core, yet Aquinas finds the opposite, that "clerics, even if they kill someone in self-defense, incur irregularity, although they intended only to defend themselves, not to kill" (Summa theologica II-II, question 64, reply to the objections 3) in Thomas Aquinas, On Law, Morality and Politics, ed. William Baumgarth and Richard Regan, trans. Richard Regan (Indianapolis: Hackett, 2002), 171.

67 Boroa, "Apología y defensorio," fol. 263r. 
As this is such a powerful (and counterintuitive) assertion, it is worth turning to at least a couple of those authors whom Boroa cites as authority such as the opinions of the Jesuit Scholastics Molina and Suárez. The Scholastic and casuistic discussions of various moral and philosophic topics by both these authors were hugely influential in their time and for many years afterwards, generating controversy and further scholarship.

Molina began publishing his treatise on justice and law (De iustitia et iure) in 1593, drawing from lectures he taught at the University of Évora on Thomas Aquinas's Summa theologica. In it, he considered the rights and morality of warfare in a series of case studies, or casuistic counsels, aimed at providing guidance to his intended readership (either confessors of princes and dignitaries, or the princes themselves). ${ }^{68}$ Given the intricate detail his Scholastic method required, not surprisingly he also considered the question of whether clerics could legitimately fight, and concludes that in some exceptional circumstances it was legitimate for them to do so. Such circumstances might be "in defense of the state or of the army, which otherwise would be destroyed or captured." 69 The circumstance that was particularly pertinent for the case of Alfaro and the besieged Paraguayan missions was "when this is necessary to obtain a just victory, from which peace and the common good of the church depends, and could not be obtained or would be endangered if they fail to fight."70

Once again, this particularly Jesuit notion of the "common good" comes to the fore. In the context of the time for the Society of Jesus (and, thus, for Molina himself), the good of the church was intrinsically intertwined with the "common good." Any attack on the church therefore constituted an attack on the people of God and vice versa. It is worth noting that Molina was teaching and writing contemporaneously to the Jesuit cardinal Robert Bellarmine (d.1621), who in 1587, drawing from Augustine's City of God, gave explicit voice to the notion that the church was under eternal, diabolical attack. ${ }^{71}$ Right-thinking Christians needed to be very sure which side they fought on in this endless war. ${ }^{72}$ Under such circumstances, Molina reasoned that if a war was advantageous to the church — and, in the context of defending the missions of Paraguay and their populations from assault by the Paulista bandeirantes there was no doubt in the minds of the Jesuits that this was the case-then it could always

\footnotetext{
68 Fernandes, "Luis de Molina: On War," 228.

69 Ibid., 242.

70 Ibid.

71 Ibid., 240.

72 In fact, the war could not be "eternal" or "endless" because teleology itself is finite. The book of Revelation made it clear that the war would end and Satan would be destroyed.
} 
be justified..$^{73}$ Perhaps more troublingly, according to Molina's argument this was true "regardless of the way or the intention with which it was waged."74 This of course had much wider and potentially very disturbing implications for the justification of warfare and required a careful policing of what being "advantageous for the church" actually meant. Nevertheless, in the case of the assaults on the missions in Paraguay, here was authoritative intellectual support for Alfaro's actions and the wider participation of Jesuit priests in the active defense of the missions and the mission populations as the people of God.

A few decades later, another Jesuit scholar, Francisco Suárez, one of the most eminent Scholastic philosophers of the early seventeenth century, meticulously discussed various moral themes and problems of conscience with respect to participation in war in his disputation on charity. At the beginning of the disputation, he asserted that by the tradition of the church (and, in particular, Saint Augustine in his polemic against the Manichees) it was even heretical to say that participation in war was an intrinsic evil, because one had to distinguish between two types of war, defensive and aggressive. ${ }^{75}$ According to his argument, participation in war was neither an intrinsic evil (in absolute terms) nor was it prohibited for Christians. According to natural law (and, by extension, divine law), one had the right to defend one's life or property, or the common good. The right to take part in a war was not prohibited to anyone (including clerics) by natural law. ${ }^{76}$ Nevertheless, Suárez then complicated the matter by distinguishing between that which natural law does not prohibit, and that which canon (or ecclesiastical) law does prohibit. According to canon law, he affirmed, it was indeed forbidden for a cleric to participate in war. ${ }^{77}$

This prohibition, he nonetheless argued, referred to an offensive war. Added to which, given that this was canon and not divine law, it could be set aside (if only for a temporary period) with permission from the pope. ${ }^{78}$ Furthermore, he said, if it were a just war, then the sin of participating would be merely one

\footnotetext{
73 Fernandes, “Luis de Molina: On War," 244.

74 Ibid.

75 Suárez, "Three Theological Virtues: On Charity; Disputation XIII: On War," 80o-65: §1:1, 80o. In fact, this is not quite what Augustine is arguing and he does not use the term "heretical." The tenor of Augustine's argument is instead to berate Faustus for not considering that violence might be done righteously (and with God's permission) to correct wrongs.

76 Suárez, "Disputation xıII: On War," §3:1, 811.

77 Ibid., §3:3, 812.

78 Ibid., §3:4, 812 .
} 
against obedience which was not as grave as a sin against justice. ${ }^{79}$ Even more significantly, if the war were unjust, then all those who participated (on the side of the unjust) would sin against justice no matter whether they were soldiers or priests.

Nevertheless, there did exist cases of "grave necessity, if the common good of the church is at stake" in which clergy "may even be obliged by natural law to engage in [defensive] war." ${ }^{\prime 80}$ In this, he is in complete agreement with Molina. This did not necessarily excuse the priest from the sin of homicide (were he to kill someone in the course of the war) but Suárez continued with the equivocation that a cleric, if he fights legitimately and kills or wounds someone in self-defense, would not $\sin .{ }^{81}$ More significantly, he highlighted a number of theologians who argued that it could even be obligatory for a cleric to commit homicide in defense of the common good given that defending the common good is much more meritorious than defending oneself. It was, he argued, practically certain that in such a case, a cleric would not sin, because it went against reason to think that evil could originate in an action that was obligated by charity. ${ }^{82}$ Although he emphasized that there were opinions to the contrary, he continued by asserting that in cases of defending the common good and the lives of others against unjust aggressors, killing was not "homicide"; rather, it was "an act of fortitude and justice." 83

In the case of the war against the Guarani missions, there was no doubt from the Jesuit perspective that this was one of the most unjust wars, and as such it was absolutely just to oppose the aggressors. This would unquestionably be in defense of the common good and in defense of the lives of others. In order to support the case for Alfaro, however, Boroa also needed to turn to scriptural precedent over and above the Scholastic arguments of his Jesuit contemporaries. Not surprisingly, then, Boroa began by citing the case of Moses who killed the Egyptian who was unjustly whipping a Hebrew slave as an authoritative precedent with which to judge the case of Alfaro. ${ }^{84}$ It was necessary, he argued, to participate in that fight against the bandeirantes in order to defend his people; given that, to the contrary, after having gathered the Guarani

79 Ibid., $\S 3: 5,812$. It is important to note here that this particular point refers only to the sin of participating in war and not to the sin of killing.

8o Suárez, "Disputation XıII: On War," §3:4, 812.

81 "He does not contract an irregularity." Ibid., §3:6, 813 .

82 Ibid., $\$ 3: 6,814$.

83 Ibid., $\$ 3: 7,815$. On this point in particular, rather than talking about the priest participating in war, he was discussing the act of encouraging soldiers to go or to participate in a just war. He compares this to exhorting a judge to make a just decision.

84 Exodus 2:11; Boroa, “Apología y defensorio, 18 Enero 1644," ARsi, Paraq. 11, fol. 263 r. 
together in "towns to receive the faith and then after having taken them in to not defend them, would be an insult to the faith, to those who preach it and it would obstruct the benefits that receiving the faith would otherwise bring, which is their eternal and spiritual salvation." ${ }^{85}$ If they were not defended, any attempt to compare the Jesuits with the good shepherd would be absurd, because it would give the impression that the Jesuits "gather them together like sheep for the slaughter." 86

Boroa continued his argument by asserting that "the obligation that parish priests have to defend their parishioners is so strict that [...] they must fulfil it even if their own lives were to be put at risk." 87 Nevertheless, he did not limit himself to citing theoretical works in order to support his reasoning, but instead wove together a net of cases of precedent in which clergy, bishops, and even popes had fought against those they considered to be enemies of the church. ${ }^{88}$ This lineage of eminent warrior clergy included Popes Leo IV (r.847-55) who saw to the defense of the city of Rome and the port of Ostia which were under attack by marauding Saracens; Leo IX (r.1049-54) who led an army to their defeat against Norman invaders of the Byzantine territories on the Italian peninsula; and Alexander VI (r.1492-1503), the controversial Borgia pope who formed an alliance against Charles vilI of France (r.1483-98) to retake the kingdom of Naples. ${ }^{89}$ Boroa recounted that throughout history "friars, priests, and even prelates of the holy orders of Saint Dominic, Francis, Augustine, the Carmelites, Mercedarians and the Society of Jesus, [have] arm[ed] themselves and gird[ed] their swords about their habits, and when the occasion demand[ed] it, they [have] fire[d] harquebuses to defend the sections of wall that the governors and magistrates assigned to them." ${ }^{\prime 90}$ Among these priestly musketeers he mentioned a Capuchin monk and a Jesuit (both anonymous) who directed the artillery in the Spanish army in Flanders apparently for no other reason than "because they were very good at it" and who, in one particular

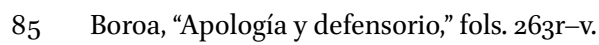

86 Ibid., fol. $263 \mathrm{v}$.

87 Ibid. Boroa cites one of the Visigothic councils of Toledo (although he does not specify which, merely referencing Toledo, book 4, and Aquinas's Summa theologica, Chapter 10, article 3) to support this argument. Aquinas in fact opposes clerics taking up arms. See the Summa theologica, part 2:2, question 40, "War," article 2, "Answer" and "Reply to the Objections," http://www.newadvent.org/summa/3040.htm, accessed April 6, 2015.

88 Boroa, "Apología y defensorio," fols. 263, 267r-269v.

89 Boroa, while not naming him, states that in 1037 a pope (Leo IV) "also with weapons in hand cast the Turks out of the kingdom of Rome” ("Apología y defensorio," fol. 263v), yet only Leo IX is generally said to have led his army into battle.

9o Ibid., fol. 267r. 
bombardment, killed the French ambassador who was standing alongside "the heretic Dutch prince of Orange."91 The warrior prelates, meanwhile, included Cardinal Francisco Ximénez de Cisneros (d.1517) who, in 1509, led the forces of Ferdinand of Aragón (d.1516) against the Moors of Oran and took the city by siege; the prince archbishop of Toledo, Sancho of Aragón, who was killed in 1275 fighting the Moors in Andalucía; and the bishop of Brazil, Don Marcos de Teixeira (d.1624), who coordinated the combined Portuguese and Spanish fight against the Dutch in Salvador da Bahía, and whose death was attributed to the burden of strategic and military governance..$^{92}$ Boroa concludes his tour of militant clerical precedent with the mention of Paraguay's own bishop, Cristóbal de Aresti (d.1638, in office 1628-35), who found himself besieged by the Paulistas in Villarrica while he was carrying out the visitation of his diocese and "rode out in person to the attack."93 All this weight of precedent he entwined with a detailed reworking of the atrocities committed by the Paulistas against the Guarani:

More than eighty thousand have been killed by arms, overwork and bad treatment without sacraments, killing both bodies and souls. This is not counting the double numbers from Guayrá, as has been proven before his Catholic Majesty, filling the countryside, roads, and fields with dead bodies and [filling] hell with the souls of these poor [victims], who fell into their hands. ${ }^{94}$

Thus, in the midst of the chaos described here, Alfaro shone like the Good Shepherd

who sweated and labored many years defending and helping his flock against those carnivorous and bloody wolves the Portuguese of Brazil. He did not carry just one lost sheep like a good Shepherd but more than fourteen thousand that he carried not just on his shoulders but also in his

91 Ibid., fol. 267r. Boroa does not try to justify this, perhaps because the justification of fighting against a heretic army would be self-evident to a Catholic readership.

For the bishop Marcos de Teixeira, see Thomas Tamaio de Vargas, Restauración de la ciudad de Salvador i Baía de Todos-Sanctos de la provincia del Brasil por las armas de don Phelippe IV el Grande, rei catholico de las Españas i Indias (Madrid: Por la viuda de Alonso Martín, 1628), fols. 42v-46r.

93 Boroa, "Apología y defensorio," fol. 26gv.

94 Ibid., fol. 264v. 
heart from the Mountains of Tape to Uruguay and Paraná, rescuing them from the rabid fury of those fierce lions. ${ }^{95}$

It was not surprising, then, that the priest who followed to the letter the role of the Good Shepherd in the parable of the lost sheep ${ }^{96}$ would become the Good Shepherd of Saint John's Gospel who loses his life defending his flock from the wolves: ${ }^{97}$ "And given that the heart of this conscientious Pastor could not bear to see his flock in danger [...] he decided to assist even though it would put himself into danger." ${ }^{\prime 8}$ In this defense, he was killed by the blast of a shotgun, and here we reach a key moment in Boroa's discourse, because he is not merely highlighting the obligation that all parish priests have to defend their parishioners; rather, he is constructing an entire trajectory of the spiritual progression of Diego de Alfaro. He began his journey by becoming a Jesuit priest and in so doing became responsible for souls through preaching and the administration of the sacraments. He became a healer of souls in other words or, as they are known colloquially in Spanish, a cura. The next step on his journey was to become an imitator of Christ, not merely because he was carrying out his office of priest and minister of the Eucharist but because he took on the role of the Good Shepherd who went out in search of his lost sheep and who ultimately sacrificed his life in their defense. Thus, he died as a martyr in imitation of Christ:

His most blessed soul flew to the tribunal of God Our Lord to present his blood that had been shed for the defense of the faith preached in those reductions, and for those poor people that had received it, and for the faithfulness of those who Our Lord had commanded to his care, for charity and love to his sheep.

\section{Conclusion}

In Boroa's apologetic account of the death of the Jesuit Diego de Alfaro, we see a confident declaration of the martyrdom and the rightness of his actions. This affirmation was notwithstanding the fact that Alfaro was participating in violence: he

95 Ibid. His reference to the exodus of the fourteen thousand must be referring to the catastrophic translocation of the mission populations in 1631.

96 Matt. 18:12-14 and Luke 15:3-7.

97 John 10:11-18.

98 Boroa, “Apología y defensorio," fol. 265 r. 
had a shotgun in his hand and it was known that he had fired it prior to his being killed. Nevertheless, he was acclaimed by his apologist as having died in imitation of Christ, as the Good Shepherd who defends his flock from the wolves and is killed in the process. The case itself is remarkable in that a Jesuit was killed fighting to defend his parishioners, while Boroa's apologia of Alfaro's actions is also remarkable in the way it draws from a wide range of materials and genres including contemporary events, historical precedent, scriptural exegesis, and Scholastic treatises in order to construct a discourse that inverted the accusations of the detractors of the Society of Jesus in the province of Paraguay and create a powerful argument for the necessity of violent resistance by the clergy to those who waged unjust war.

The extraordinary nature of both the case itself and its apologetic analysis may lead to the logical conclusion that, while distinctive, it is not distinctively Jesuit. This argument holds particular weight when, in the absence of the reply to Boroa's apologia, it is necessary to refer back to the early rules and instructions of the Society which exhorted charity rather than violence in the actions of its members and pragmatic caution when faced with situations of danger. As a counterpoint to this, however, this essay has argued that what makes the case an exemplar of the quidditas jesuitica is, first, that it was charity that obliged them to defend the defenseless; while, secondly, that this was understood by the Jesuits of the province of Paraguay as taking place in the context of the eternal war that was being waged on the City of God by the devil and his hosts. The Jesuit perception of this war, meanwhile, framed their understanding and representation of the catastrophic attacks that the Paulista bandeirantes were carrying out on the frontier missions - these were part of the diabolical assault on the church and the people of God. Thus, effective resistance was imperative, in whatever ways they could, whether that was through lobbying the papacy to excommunicate those who participated in the raids, and the Spanish crown and its representatives in a campaign to permit the Guarani to use firearms and to be trained in the techniques of modern European warfare, or whether it was to participate themselves in the urgent and necessary defense of their communities. According to the Jesuit theorist Luis de Molina, any war could be considered just if it were fought in defense of the church and the common good, and under these circumstances, it was also legitimate for clergy to fight. So too, Francisco Suárez argued that in order to defend the common good, clergy could participate in battle. The canonical prohibitions were of secondary importance compared to the obligation to protect the common good. And this is what unified the Jesuits in the province of Paraguay in their determination to protect the missions and their populations. It was what lay at the heart of the founding document of the Society-the Formula of the Institute of the Society - the exhortation to carry out those works of charity 
most convenient for the glory of God and for the common good. All this, Boroa drew on, as well as his vast experience as a Jesuit missionary on the Paraguayan frontier and the wealth of rhetorical learning his Jesuit formation had given him, in order to create a passionate argument that centered on the obligations of charity and justice to act. Could a priest take up arms against the hosts of the antichrist? As Boroa would have it, basing his argument on the evidence of the atrocities committed, the Scholastic shield walls provided by his fellow Jesuits Molina, Suárez, Lessius, and others, the weight of historical precedent and the scriptural imperative to imitate Christ as the Good Shepherd, the answer was a resounding yes. Not only could a priest take up arms but it would be a mortal sin not to do so. 